\title{
Temporal resolution of biological and physical influences on bay anchovy Anchoa mitchilli egg abundance near a river-plume frontal zone
}

\author{
Ernst B. Peebles* \\ College of Marine Science, University of South Florida, 140 Seventh Avenue SE, St. Petersburg, Florida 33701, USA
}

\begin{abstract}
Bay anchovy egg abundance in the Manatee River estuary, Florida, was compared with conditions in the spawning ground before and after spawning to distinguish prey-supply-based spawning responses from post-spawning advective effects. Plume fronts were a prominent feature of the spawning ground. Egg distribution, copepod distribution and front development were surveyed 25 times across a wide range of freshwater inflow conditions. Surface-front strength (maximum interpolated salinity slope) was strongly correlated with the size of the frontal zone, as defined by surface areas having slopes $>1 \mathrm{psu} \mathrm{km}^{-1}$. Eggs were most abundant landward of the frontal zone at a location with consistently high abundance of the copepod Acartia tonsa, which is consumed by adult and larval bay anchovies. Large, significant changes in egg abundance were observed over both long (seasons) and short (<3 d) periods (Tukey 95\% HSD multiple range tests). An El Niño-associated flood event caused the rapid evolution of a large, seaward-moving frontal system that initially had a negative effect on egg abundance. Spawning resumed in reduced salinity following passage of the front, demonstrating a level of plasticity in spawning response to salinity change. A stepwise regression model explained $92 \%$ of the variation in egg abundance and suggested that tidal amplitude was not a significant determinant of abundance. Instead, egg abundance appeared to be determined initially by pre-spawning prey supply and temperature, and subsequently by variable retention behind the frontal zone.
\end{abstract}

KEY WORDS: Iteroparity $\cdot$ Egg development $\cdot$ Population dynamics $\cdot$ Stock recruitment $\cdot$ Life history strategy $\cdot$ Plankton patchiness $\cdot$ Estuarine retention · Tampa Bay

Resale or republication not permitted without written consent of the publisher

\section{INTRODUCTION}

The bay anchovy is a small, abundant planktivore that is of great trophic importance to larger fishes and seabirds. Adults broadcast their planktonic eggs in association with tributary plumes, residual circulation eddies and convergent physical features that tend to aggregate plankton (Castro \& Cowen 1991, Wang \& Houde 1994, Peebles et al. 1996, Hood et al. 1999). As a subject for study, the bay anchovy's habit of spawning close to shore makes this species a tractable representative of the large group of neritic-pelagic marine fishes that are iteroparous broadcast spawners.

*E-mail: epeebles@seas.marine.usf.edu
In some fishes, inconsistency in the seasonal alignment between spawning effort and larval food supply is thought to cause strong inter-annual variation in the proportion of larvae that starve or become more susceptible to predation as the result of low ration (match/mismatch hypothesis, Cushing 1990). Plagányi et al. (2000) provide evidence for adding a spatial component to the match/mismatch hypothesis, which they identify as being particularly important in heterogeneous ecosystems. However, it has been demonstrated for a number of species that fecundity is not simply proportionate to spawner biomass, but instead exhibits size-specific variation (Bagenal 1973, Ware 1980, Tsuruta \& Hirose 1989, Luo \& Musick 1991). The question then arises as to whether variation in spawn- 
ing intensity is large enough to be considered, along with match/mismatch, to be another cause of poor fit between adult biomass and subsequent recruitment.

The supply of anchovy eggs is determined by 3 processes: (1) the distribution of spawning effort; (2) subsequent advection of the spawned eggs; and (3) mortality losses, which may result from direct consumption by predators (Monteleone \& Duguay 1988, Cowan \& Houde 1993, Purcell et al. 1994) or sinking to bottom waters after loss of viability (Iseki \& Kiyomoto 1997). Positive associations between bay anchovy egg density and zooplankton prey abundance are likely to result from combinations of these processes, but cannot be caused by match/mismatch because eggs do not consume prey.

Considering Process 1, it has been widely suggested that the planktivorous adults spawn more heavily in zooplankton-rich locations either because the adult energetic capacity is higher there or because of selection for the trait of spawning where larval food is most abundant (Castro \& Cowen 1991, Dorsey et al. 1996, Peebles et al. 1996, Hood et al. 1999). During daylight hours, the adult bay anchovy diet is dominated by adult calanoid copepods (Darnell 1961, Sheridan 1978,

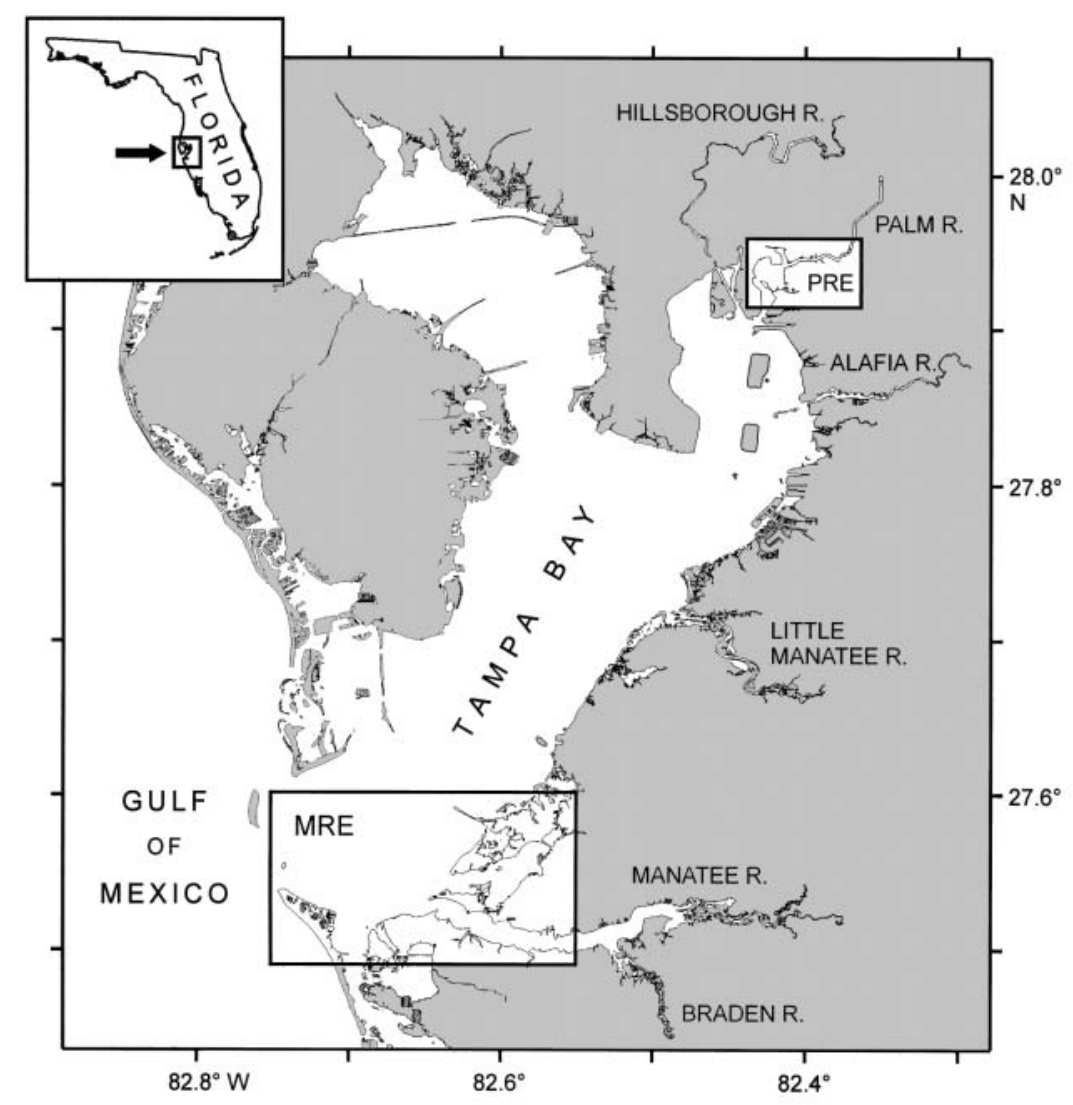

Fig. 1. Position of the Manatee River estuary (MRE) and Palm River estuary (PRE) survey areas relative to other Tampa Bay tributaries
Johnson et al. 1990, Peebles et al. 1996). If large numbers of adult copepods are encountered by adult anchovies during the day (before spawning), then large numbers of copepod nauplii are also likely to be present in the same waters because adult calanoids and nauplii tend to be spatio-temporally correlated (Peebles et al. 1996). The correlation provides adult bay anchovies with a potential signal for the availability of nauplii, which are important prey for anchovy larvae (Houde \& Lovdal 1984). This hypothetical copepod signal (copepod abundance or aggregation) is likely to be established during the day many hours before the nighttime spawning event, whereas the patterns produced by advection and mortality would be superimposed after spawning. A temporal separation, therefore, distinguishes the effects of Process 1 from those of Processes 2 and 3. With this in mind, I designed a sampling regime that repeatedly compared egg abundance with copepod availability before and after spawning. The calanoid copepod Acartia tonsa is the biomass-dominant zooplankter in Tampa Bay, Florida, USA (Hopkins 1977) and is a principal diet item for the first year adult bay anchovies that produce the majority of eggs (Darnell 1961, Sheridan 1978, Zastrow et al. 1991, Peebles et al. 1996). This species was used as an index of coupled adult/larval prey availability.

The Manatee River estuary (MRE, Fig. 1) was selected for study primarily because its plume region is spatially isolated. Preliminary egg surveys confirmed that the MRE has a relatively isolated bay anchovy spawning ground as well, whereas the spawning grounds associated with the other Tampa Bay tributaries tend to intermix, particularly during rainy periods (Peebles et al. 1996). During much of the year, the spawning ground in the MRE has riverplume fronts associated with it (cf. Largier 1993, O'Donnell 1993). These fronts, which are marked by abrupt changes in water color and salinity, occur at a spatial scale below the resolution of most hydrodynamic models. Plume fronts may serve as barriers to the dispersal of plankton (Largier 1993), and the larger ones are often characterized by localized concentrations of $\mathrm{chl} a$ and zooplankton (Govoni et al. 1989, Lohrenz et al. 1990, Dagg \& Whitledge 1991).

The present study was scaled to encompass both the river-plume frontal zone (RPFZ) and the larger bay anchovy spawning ground. The principal objective was to compare the influence of preyrelated variation in spawning effort (Pro- 
cess 1) with variation in front-related egg retention (Process 2) across a wide range of freshwater inflow conditions. Reliable knowledge of spawning and hatching times is critical to this objective, given the intended approach of comparing pre- and post-spawning conditions to identify determinants of egg abundance. In the Chesapeake Bay area, spawning is reported to occur during the first half of the night, with hatching taking place $<24$ h later (Cowan \& Houde 1990, Luo \& Musick 1991, Zastrow et al. 1991). Individual females may spawn $>50$ times $\mathrm{yr}^{-1}$, and it is possible for the stock as a whole to spawn on consecutive nights for several months at a time (Luo \& Musick 1991, Zastrow et al. 1991). If these reported spawning and development parameters also apply to the Tampa Bay area, then all eggs collected during the day from the MRE originate from the previous night's spawning effort. The sampling design that was developed to address the primary objective assumes that consecutive daytime surveys will collect consecutive, but discrete, nightly egg cohorts. Verification of this assumption in the Tampa Bay area became a secondary objective.

\section{MATERIALS AND METHODS}

Determinants of egg abundance. Five series of egg and copepod surveys were conducted, with each series consisting of 5 consecutive days of surveys, producing a total of 25 complete surveys. Starting dates were: 26 August 1997 (Series 1), 29 September 1997
(Series 2), 27 April 1998 (Series 3), 27 October 1998 (Series 4) and 26 April 1999 (Series 5). Two series were conducted at the end of wet periods (Series 1 and 4) and 2 were conducted during dry periods (Series 3 and 5). The remaining series (Series 2) was conducted during an isolated peak of freshwater inflow into the survey area (Fig. 2). The 2 dry period series were conducted in consecutive years during the same week of the year.

Blocking into $5 \mathrm{~d}$ series permitted evaluation of day-to-day changes in egg abundance and allowed daily copepod surveys to represent prey availability both before and after spawning (the resemblance to a random-block design is superficial). The first day's copepod catch represented the pre-spawning prey availability associated with the first night's spawning. The second day's egg catch represented the first night's spawning effort and the second day's copepod catch represented both post-spawning prey avail-
Fig. 3. Sampling route followed during the egg and copepod surveys of the Manatee River estuary (MRE). Each sampling series (Fig. 2) started within the river and consisted of 1 plankton net tow at each of 19 locations (arrows) on 5 consecutive days. Diagonal lines identify the average locations of the river-plume frontal zone (RPFZ, salinity slopes $>1.0 \mathrm{psu}$ $\mathrm{km}^{-1}$ ) and the tidal intrusion frontal zone (TIFZ); the location of the TIFZ was observed to coincide with areas of tidal shear defined by the Burwell et al. (1999) hydrodynamic model

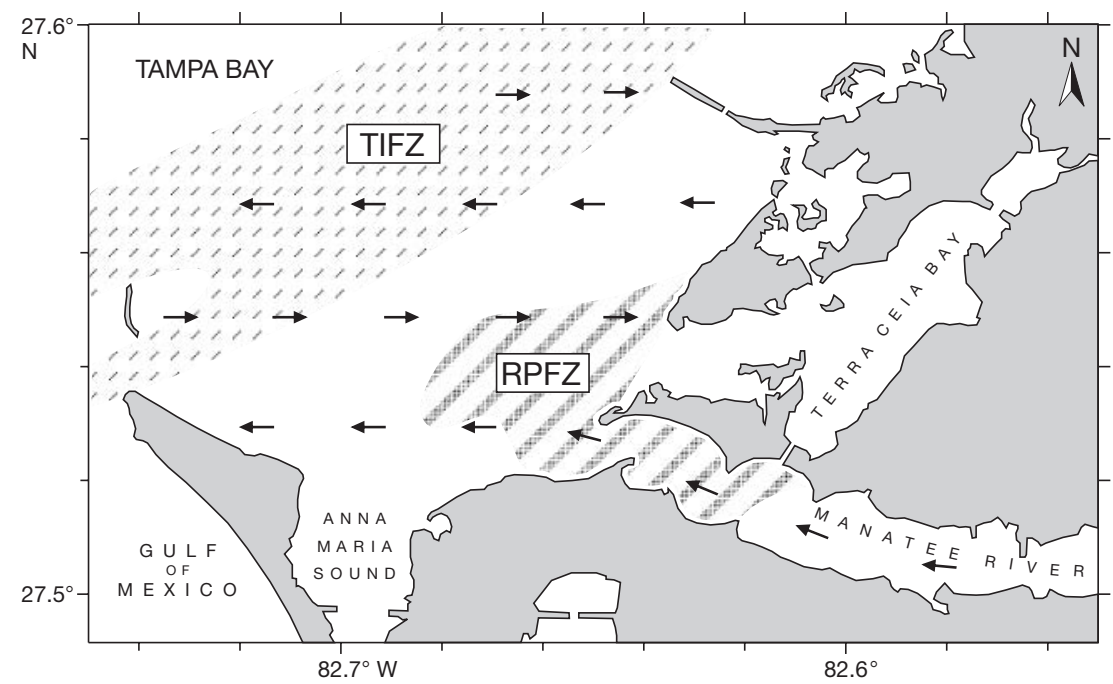


ability for the first night's spawning and pre-spawning prey availability for the second night's spawning. Accordingly, all but the last day of a $5 \mathrm{~d}$ series provided pre-spawning prey data and all but the first day provided post-spawning prey data, producing 4 sets of paired, $1 \mathrm{~d}$ lagged observations for each $5 \mathrm{~d}$ series.

Each of the 25 surveys consisted of a single collection at 19 fixed stations (Fig. 3). Station depth ranged from 0.9 to $5.2 \mathrm{~m}$ and averaged $3.4 \mathrm{~m}$. Each day's sampling began between 09:00 and 10:00 $\mathrm{h}$ and was completed in an average of $3.2 \mathrm{~h}$.

Each collection consisted of a single 1 min surface tow with a $0.5 \mathrm{~m}$ mouth, $333 \mu \mathrm{m}$ mesh plankton net towed at approximately $1 \mathrm{~m} \mathrm{~s}^{-1}$. This gear fully retains bay anchovy eggs and selects for copepod sizes similar to those found in adult bay anchovy stomachs (Peebles et al. 1996). Filtered volume $\left(\bar{x}=18.5 \mathrm{~m}^{3}\right)$ was estimated using calibrated flowmeters. Surface salinity and water temperature were measured electronically. Bay anchovy eggs and Acartia tonsa were enumerated from 6 to $10 \mathrm{ml}$ aliquots that were poured immediately after repeatedly inverting the entire plankton sample $(\bar{x}=722 \mathrm{ml})$ within a graduated cylinder.

Bay anchovy eggs become less buoyant at low salinities (Jones et al. 1978, Rilling \& Houde 1999a), which may reduce egg abundances in surface tows and give the false impression that egg abundances are reduced in low salinities. Each month from May 1997 to June 1998 and from April to June 1999, a $30 \mathrm{~km}$ transect extending from the mouth of the Manatee River to its oligohaline/freshwater reaches was surveyed using $5 \mathrm{~min}$ bottom-to-surface (oblique) tows at 14 evenly spaced stations (238 tows, filtered volume $\bar{x}=83 \mathrm{~m}^{3}$ ). Vertical salinity and temperature profiles were measured in association with each deployment. Data from the 17 oblique-tow surveys were used to define salinity structures and upstream egg limits within the Manatee River.

Spearman's rank correlations between eggs and copepods were measured using densities (ind. $\mathrm{m}^{-3}$ ) from individual plankton tows made during the 25 surface-tow surveys. The extent to which copepods were spatially aggregated was measured using a varianceto-mean ratio, IC $=\left(s^{2} / \bar{x}\right)^{-1}$ (David \& Moore 1954), where $\bar{x}$ is the mean and $s^{2}$ is the variance of the copepod densities observed at 19 locations. Densities from individual tows could not be directly used to compare egg and copepod abundance among surveys because of wide variation in the volumes represented by different stations. Instead, total numbers in the top meter of the study area were estimated by integrating interpolated densities over both the northern and eastern distance axes, which were scaled in meters (kriging, linear semivariogram model, Surfer 7, Golden Software
1999). Data faults were used to prevent interpolation across land masses. The same methods were employed to interpolate isohaline positions and to calculate the slope of the surface salinity gradient (psu km${ }^{-1}$ ). The horizontal slope at interpolated grid nodes was calculated throughout $360^{\circ}$, rather than restricting the estimates to the pre-defined axes of directional derivatives. Plume-front area was defined as the area of surface waters having a salinity slope $>1.0 \mathrm{psu} \mathrm{km}^{-1}$. Plume-front strength was represented by the maximum nodal slope.

Stepwise multiple regression (Lohrenz et al. 1990, Draper \& Smith 1998; Statgraphics Plus 5, Manugistics) was used to identify variables that were associated with variation in egg abundance among the 25 surveys. The following regressors were evaluated:

Season regressors: $T$, water temperature $\left({ }^{\circ} \mathrm{C}\right.$, mean of 19 locations); $P$, photoperiod (min, sunrise to sunset).

Prey regressors: $A N_{\text {pre, }}$ pre-spawning Acartia tonsa number ( $\times 10^{9}$ in $1 \mathrm{~m}$ surface layer); $A N_{\text {post }}$ post-spawning $A$. tonsa number $\left(\times 10^{9}\right.$ in $1 \mathrm{~m}$ surface layer); $A A_{\text {pre }}$ pre-spawning $A$. tonsa aggregation (IC); $A A_{\text {post }}$ postspawning $A$. tonsa aggregation (IC).

Front regressors: $F M_{\text {pre, }}$ pre-spawning salinity mean (psu), the mean of 19 locations; $F M_{\text {post }}$ post-spawning salinity mean (psu), the mean of 19 locations; $F V_{\text {pre }}$ pre-spawning salinity standard deviation (psu), the SD of 19 locations; $F V_{\text {post }}$ post-spawning salinity standard deviation (psu), the SD of 19 locations; $F A_{\text {pres }}$ prespawning front area $\left(\mathrm{km}^{2}\right)$, delineated by slopes $>1.0 \mathrm{psu} \mathrm{km}{ }^{-1} ; F A_{\text {post, }}$ post-spawning front area $\left(\mathrm{km}^{2}\right)$, delineated by slopes $>1.0 \mathrm{psu} \mathrm{km}^{-1}$; $F S_{\text {pre, }}$ pre-spawning front strength (psu km${ }^{-1}$ ), the maximum horizontal slope; $F S_{\text {post }}$ post-spawning front strength $\left(\mathrm{psu} \mathrm{km}^{-1}\right)$, the maximum horizontal slope.

Tide regressors (levels at St. Petersburg NOAA gauge adjusted to study area): $D_{24 \mathrm{~h}}$, tide strength (m), the sum of water level increases from 00:00 to 24:00 $\mathrm{h}$ on spawning day; $D_{\text {night }}$ tide strength (m) at night, the sum of water level increases between sunset on day of spawning and sunrise on day of survey; $D_{\text {spawn }}$ tide strength $(\mathrm{m})$ during spawning hours, the sum of water level increases during first $4 \mathrm{~h}$ after sunset on spawning day.

Prior to entry into the forward stepwise regression, the normality of each regressor was evaluated using standardized kurtosis and skewness coefficients. Ln transformations were substituted whenever an improvement in normality resulted $(F A+1$ was used to accommodate zero values). Relationships within the selected subset of regressors ( $F$-to-enter and $F$-to-exit based on $\alpha=0.05$ ) were examined for signs of nonlinearity and collinearity by examining scatterplots, Studentized residuals, partial Studentized residuals, and correlations among regressors that contribute to 
variance inflation (Ryan 1997, Draper \& Smith 1998). The partial fits of pre- and post-spawning regressor pairs were compared by substituting individual regressors while holding all other regressors within the selected subset constant (non-stepwise multiple regression).

Verification of spawning and hatching times. During the spring of 2000, which was an exceptionally dry period, a portion of the bay anchovy's spawning ground extended into the Palm River estuary (PRE), a nearly confined area that narrowly connects to Tampa Bay (Fig. 1). Given the small size and confined nature of the PRE, probability was high that samples from this area would contain bay anchovy eggs at this time. On 2 dates, 27 April and 3 May, single plankton net samples were taken from 16 locations. The samples were taken at 10 to $15 \mathrm{~min}$ intervals between 19:30 and 23:30 h Eastern Standard Time. Collections were made using $5 \mathrm{~min}$ bottom-to-surface tows with a $500 \mu \mathrm{m}$ mesh, $0.5 \mathrm{~m}$ mouth net towed at approximately $1 \mathrm{~m} \mathrm{~s}^{-1}$, with sample fixation in 5 to $10 \%$ formalin followed by preservation in $50 \%$ isopropanol. At $90 \times$ magnification, bay anchovy eggs were staged as: unfertilized (no perivitelline space and no thickening at the animal pole), blastodisc (no cleavage), early cleavage ( 2 to 64 blastomeres), morula (>64 blastomeres) or late embryo (tail free, optic and auditory vesicles formed). I staged either all eggs or a maximum of 100 eggs from each sample. Spawning and hatching times were inferred from time-series plots of egg-stage composition (Holt et al. 1985, Luo \& Musick 1991).

\section{RESULTS}

\section{Front characteristics}

The range of front behaviors observed during this study represents a large part of the natural variability that is to be expected. The isolated inflow event that was monitored during Series 2 (Fig. 2) was the first of 7 events of similar magnitude, each caused by the passage of exceptionally rainy cold fronts during the 1997-98 El Niño period. The largest of these rain events, which passed through in mid-November 1997, produced the highest flows recorded in the Manatee River since monitoring began in 1967. When combined with the summer rainy season, the latter 3 of the 7 fronts made 1998 the wettest year on record for this estuarine tributary. Series 3 was conducted during the 1998 spring dry season, which was a dry season that followed the unusually wet period. Salinities in Tampa Bay remained reduced at this time despite a lack of recent rainfall. In this regard, Series 5 was more representative of the typical spring dry season than was Series 3.
Both wet periods preceding Series 1 and 4 had freshwater inflow levels that were representative of the summer wet season. Distinct pycnoclines were not common in the Manatee River, even near the frontal zone. During the peak of the summer rainy season in early August 1997, the water column was entirely fresh (<1.0 psu) upstream of $16 \mathrm{~km}$. Vertical density profiles at 8 locations in the lower $16 \mathrm{~km}$ of river had nearly constant slopes in the range of 0.3 to $3.4 \mathrm{~kg} \mathrm{~m}^{-3} \mathrm{~m}^{-1}$, with the high end of this range occurring upstream between 12 and $16 \mathrm{~km}$.

The results of the 25 surveys are summarized in Table 1. The various front-related regressors represent the same variable, front development, and are largely interchangeable. All of these were strongly correlated (Pearson correlation). Front strength (maximum salinity slope) was positively correlated with salinity standard deviation $(\mathrm{r}=0.98, \mathrm{n}=25, \mathrm{p}<0.001)$ and front area $(\mathrm{r}=0.88, \mathrm{n}=17, \mathrm{p}<0.001)$, and was negatively correlated with mean salinity $(\mathrm{r}=-0.75, \mathrm{n}=25, \mathrm{p}<$ $0.001)$. Front area was negatively correlated with mean salinity $(r=-0.78, n=17, p<0.001)$. However, the estimates of front area, as defined here, contained a number of zero observations that reduced this parameter's utility for explaining variation in egg abundance.

\section{Egg and copepod front associations}

Acartia tonsa constituted $79 \%$ of the copepods collected. This species formed patches both inshore and offshore of the RPFZ, and there were no apparent increases in concentration within the RPFZ itself. Most bay anchovy eggs were associated with the inshore patch; a comparison of composite distributions is presented in Fig. 4. The locations of discrete patches are averaged in Fig. 4, which renders the offshore A. tonsa patches less apparent. The inshore patch was more consistently placed, being present within the lower Manatee River in 22 of the 25 surveys. The 3 exceptions occurred during the first days of Series 2, when freshwater inflows were exceptionally high. The inshore patches of both copepods and bay anchovy eggs occurred within a few kilometres of the plume front whenever the plume front was established (Fig. 5A), generally peaking upstream of the frontal zone. During dry periods (Series 3 and 5), front formation was weak or absent and only the inshore $A$. tonsa and egg patches were developed (Fig. 5B). Egg densities estimated from the 17 oblique-tow transects were low, but followed the same pattern as in Fig. 4, with mean densities being highest (11.6 eggs $\mathrm{m}^{-3}$ ) at a location $4.2 \mathrm{~km}$ upstream of the river mouth. Farther upstream $(>10 \mathrm{~km})$, oblique-tow densities averaged $<0.2$ eggs $\mathrm{m}^{-3}$ at all locations. 
Table 1. Survey data used in the stepwise regression. Anchoa mitchilli egg number (Eggs), mean water temperature ( $T$ ), photoperiod $(P)$, Acartia tonsa number $(A N)$, A. tonsa aggregation $(A A)$, salinity mean $(F M)$, salinity standard deviation $(F V)$, front area $(F A)$, front strength $(F S)$, daily tide strength $\left(D_{24 \mathrm{~h}}\right)$, nighttime tide strength $\left(D_{\text {night }}\right)$ and tide strength during spawning hours $\left(D_{\text {spawn }}\right)$. Asterisk identifies regressors for which ln transformation improved conformity to a normal probability distribution

\begin{tabular}{|c|c|c|c|c|c|c|c|c|c|c|c|c|c|}
\hline Series & Day & $\begin{array}{l}\text { Eggs } \\
\left(\times 10^{6}\right)\end{array}$ & $\begin{array}{c}T \\
\left({ }^{\circ} \mathrm{C}\right)\end{array}$ & $\begin{array}{c}P \\
(\min )\end{array}$ & $\begin{array}{l}A N^{*} \\
\left(\times 10^{9}\right)\end{array}$ & $\begin{array}{l}A A^{*} \\
(I C)\end{array}$ & $\begin{array}{c}F M \\
(\mathrm{psu})\end{array}$ & $\begin{array}{l}F V^{*} \\
(\mathrm{psu})\end{array}$ & $\begin{array}{l}F A^{*} \\
\left(\mathrm{~km}^{2}\right)\end{array}$ & $\begin{array}{c}F S^{*} \\
\left(\mathrm{psu} \mathrm{km}^{-1}\right)\end{array}$ & $\begin{array}{l}D_{24 \mathrm{~h}} \\
(\mathrm{~m})\end{array}$ & $\begin{array}{c}D_{\text {night }} \\
(\mathrm{m})\end{array}$ & $\begin{array}{c}D_{\text {spawn }} \\
(\mathrm{m})\end{array}$ \\
\hline 1 & 1 & 16824.0 & 29.7 & 773 & 178.2 & 9168.7 & 27.5 & 3.30 & 10.49 & 3.33 & 0.63 & 0.30 & 0.00 \\
\hline 1 & 2 & 13921.4 & 28.7 & 771 & 76.3 & 489.4 & 29.0 & 2.92 & 8.05 & 1.82 & 0.65 & 0.31 & 0.01 \\
\hline 1 & 3 & 11724.1 & 29.0 & 770 & 77.1 & 1293.1 & 28.7 & 2.72 & 1.89 & 1.76 & 0.79 & 0.51 & 0.13 \\
\hline 1 & 4 & 8806.8 & 29.1 & 768 & 75.9 & 323.5 & 28.6 & 2.67 & 2.30 & 2.20 & 0.78 & 0.47 & 0.23 \\
\hline 1 & 5 & 9327.9 & 29.2 & 767 & 69.0 & 259.0 & 28.4 & 2.55 & 1.91 & 2.24 & 0.78 & 0.43 & 0.29 \\
\hline 2 & 1 & 868.0 & 27.6 & 718 & 106.8 & 637.6 & 22.4 & 9.80 & 40.30 & 8.18 & 0.67 & 0.40 & 0.22 \\
\hline 2 & 2 & 1689.4 & 27.5 & 716 & 119.1 & 1821.3 & 18.6 & 8.85 & 67.42 & 7.09 & 0.80 & 0.46 & 0.29 \\
\hline 2 & 3 & 4852.3 & 28.2 & 715 & 157.6 & 1489.1 & 19.5 & 7.69 & 66.34 & 5.89 & 0.88 & 0.48 & 0.32 \\
\hline 2 & 4 & 6983.5 & 28.2 & 713 & 172.4 & 2188.5 & 17.4 & 6.74 & 45.95 & 6.28 & 0.93 & 0.49 & 0.45 \\
\hline 2 & 5 & 7196.9 & 27.6 & 712 & 98.8 & 571.1 & 18.9 & 7.26 & 42.63 & 6.26 & 0.86 & 0.40 & 0.28 \\
\hline 3 & 1 & 1365.5 & 23.3 & 787 & 269.2 & 6241.5 & 25.1 & 2.16 & 6.31 & 1.80 & 1.10 & 0.50 & 0.45 \\
\hline 3 & 2 & 4833.1 & 24.0 & 788 & 535.1 & 44964.9 & 24.8 & 1.97 & 2.83 & 1.67 & 1.03 & 0.49 & 0.36 \\
\hline 3 & 3 & 7517.4 & 23.9 & 789 & 156.9 & 1031.0 & 24.9 & 1.97 & 2.12 & 1.57 & 0.90 & 0.46 & 0.22 \\
\hline 3 & 4 & 4677.3 & 23.0 & 791 & 177.2 & 1509.1 & 26.6 & 2.11 & 0.00 & 1.00 & 0.91 & 0.48 & 0.12 \\
\hline 3 & 5 & 4546.6 & 23.3 & 793 & 177.9 & 3218.7 & 26.2 & 2.13 & 0.00 & 1.33 & 0.88 & 0.58 & 0.10 \\
\hline 4 & 1 & 32.3 & 23.0 & 673 & 88.8 & 861.3 & 25.0 & 2.21 & 13.61 & 2.37 & 0.69 & 0.15 & 0.01 \\
\hline 4 & 2 & 18.8 & 24.2 & 672 & 165.4 & 869.8 & 24.1 & 2.09 & 6.68 & 1.78 & 0.71 & 0.20 & 0.04 \\
\hline 4 & 3 & 0.0 & 24.1 & 671 & 105.6 & 826.3 & 24.4 & 1.88 & 2.69 & 1.69 & 0.66 & 0.22 & 0.05 \\
\hline 4 & 4 & 14.7 & 24.3 & 669 & 66.4 & 429.3 & 24.6 & 1.77 & 0.00 & 1.04 & 0.73 & 0.36 & 0.13 \\
\hline 4 & 5 & 0.0 & 24.7 & 667 & 94.0 & 788.1 & 25.0 & 1.74 & 0.00 & 1.22 & 0.80 & 0.49 & 0.24 \\
\hline 5 & 1 & 3532.8 & 26.2 & 785 & 12.1 & 205.3 & 28.2 & 1.58 & 11.38 & 1.91 & 0.82 & 0.30 & 0.09 \\
\hline 5 & 2 & 544.1 & 26.9 & 786 & 13.1 & 188.5 & 27.9 & 0.93 & 0.00 & 0.93 & 0.88 & 0.37 & 0.23 \\
\hline 5 & 3 & 610.8 & 27.1 & 788 & 15.7 & 324.5 & 28.2 & 1.06 & 0.00 & 1.13 & 0.85 & 0.37 & 0.26 \\
\hline 5 & 4 & 678.9 & 26.7 & 789 & 28.6 & 132.5 & 28.6 & 0.88 & 0.00 & 0.69 & 0.71 & 0.33 & 0.26 \\
\hline 5 & 5 & 624.5 & 26.5 & 791 & 28.8 & 214.5 & 28.1 & 0.83 & 0.00 & 0.73 & 0.94 & 0.50 & 0.45 \\
\hline
\end{tabular}

The strong frontal system that was observed during Series 2 originated upstream at the onset of elevated inflows and progressed downstream though the region where inshore patches typically formed, dispersing organisms in the offshore direction (Fig. 5C). As the Series 2 frontal system eventually began to retreat landward, the inshore Acartia tonsa patch re-developed near the river mouth, even though salinities there had been reduced from 24-28 to 12-18 psu. Bay anchovy egg production intensified slightly seaward of this newly developed inshore patch (Fig. 5D), increasing by a factor of 8.3 over the $5 \mathrm{~d}$ period (from $0.87 \times 10^{9}$ to $7.2 \times 10^{9}$, Table 1 ). Daily changes in instantaneous egg densities within Series 2 (mean increase from 8.2 to 67.4 eggs $\mathrm{m}^{-3}$ ) were statistically significant at periods $<3 \mathrm{~d}$, as were differences among series (Tukey 95\% HSD multiple range tests, ln-transformed values, Fig. 6).

Bay anchovy eggs and Acartia tonsa were concentrated in lower salinities than other copepods and the eggs of the striped anchovy Anchoa hepsetus. The density-weighted mean salinities at capture were: $A$. tonsa, 24 psu < Anchoa mitchilli eggs, 25 psu < Labidocera aestiva, $27 \mathrm{psu}<A$. hepsetus eggs, $28 \mathrm{psu}$. The latter 2 organisms were consistently most abundant seaward of the frontal zone.

\section{Determinants of egg abundance}

Stepwise regression explained $92 \%$ of the temporal variability in egg abundance. Photoperiod was significantly correlated with mean salinity $(\mathrm{r}=0.56, \mathrm{n}=25$, $\mathrm{p}=0.004$ ) and contributed $3.5 \%$ to the explained variation. With photoperiod excluded to reduce the potential for variance inflation, the selected regressor subset remained otherwise unchanged, explaining $88 \%$ of the variation. Although the Durbin-Watson statistic was $1.52(p=0.01)$, a plot of residuals versus order did not produce a pattern indicative of serial correlation. The regression's performance is plotted in Fig. 7 .

Variation in egg abundance was primarily associated with variation in pre-spawning Acartia tonsa number $\left(A N_{\text {pre }}, 40.8 \%\right)$, water temperature $(27.3 \%)$ and mean salinity after spawning (20.4\%, Table 2$)$. Variation in $A N_{\text {pre }}$ explained most of the intra-series egg abundance variation in Series 1, 2 and 3 (Fig. 8). Low values for $A N_{\text {pre }}$ accounted for the low egg abundance during Series 5. A combination of terms explained the low egg abundance during Series 4 .

The stepwise regression performed well in the sense that it selected no more than 1 regressor from each group of related regressors and the signs of the coeffi- 


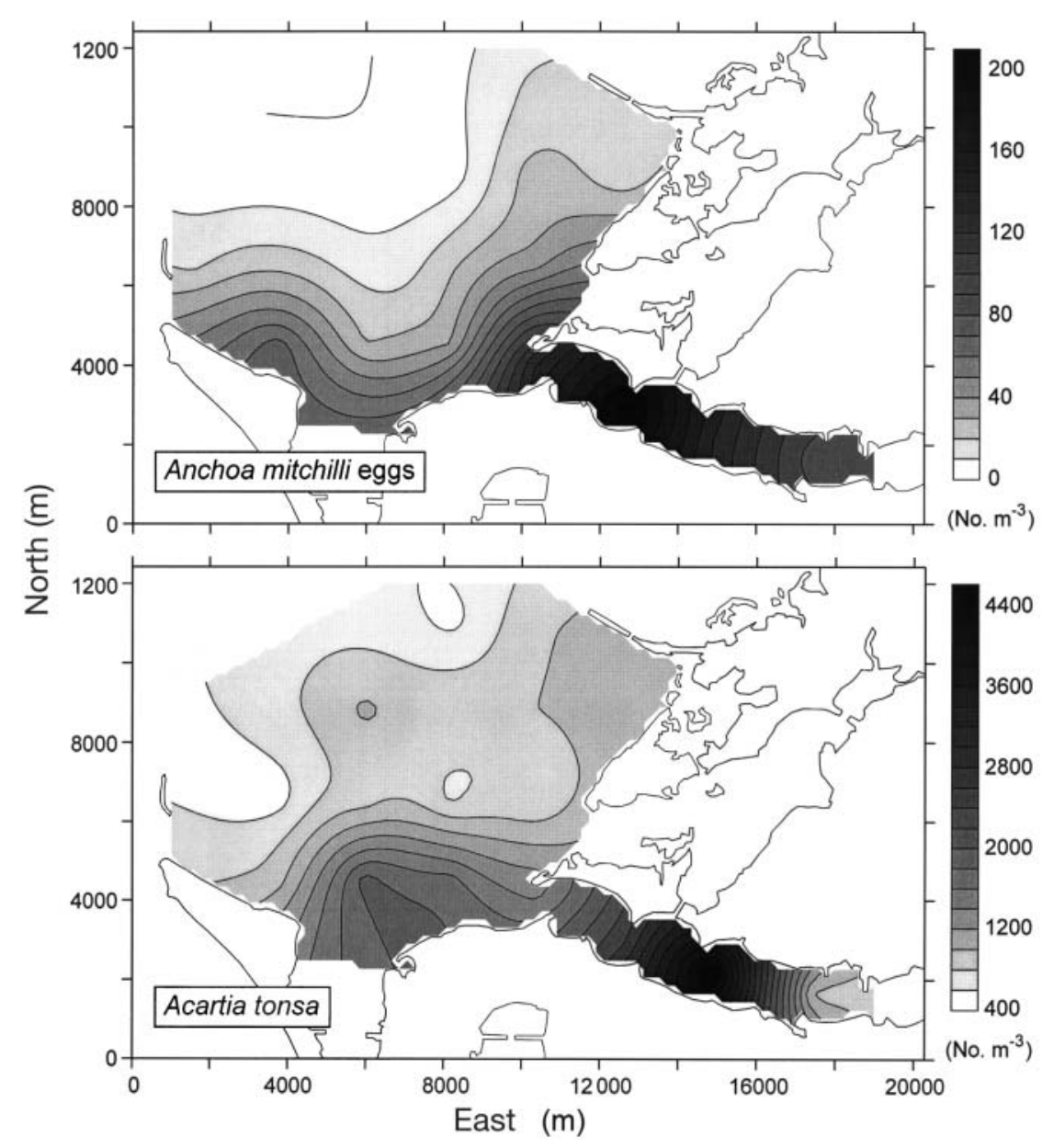

Fig. 4. Mean organism density using data from 25 surveys

embryo eggs that were collected prior to NT. Between 1 and $3 \mathrm{~h}$ after NT on both dates, the abundance of newly fertilized eggs (blastodisc stage) increased markedly. During the 27 April spawning event, the blastodisc peak was partly missed as the sampling route was followed into the Palm River, away from the center of spawning activity (Fig. 10). By the time sampling was resumed in McKay Bay at 22:20 h, early cleavage had become the dominant stage (Fig. 9). During the 3 May spawning event, egg distributions extended farther upstream (Fig. 10), resulting in better sampling resolution of the blastodisc peak. Peak spawning, as indicated by dominance of the blastodisc stage, was centered approximately $2 \mathrm{~h}$ after NT and lasted approximately $1.5 \mathrm{~h}$. Blastodisc, early cleavage and morula stages peaked in order of development.

Newly hatched yolk-sac larvae first appeared within a few minutes of NT on both dates (first appearance at 20:00 and 20:10 h). Hatching appeared to be complete within $2.5 \mathrm{~h}$ after NT on both dates, as indicated by the complete absence of lateembryo eggs after 22:30 h. Comparison of peak spawning and hatching

cients agreed with expected relationships. The salinity term in the regression was positive because egg densities were low at the onset of the wash-out event (Series 2) and were high during the high mean salinities of Series 1.

Spearman's rank correlations between instantaneous bay anchovy egg and Acartia tonsa densities were evident in 3 of the 5 series (Series 2: $\mathrm{r}=0.29, \mathrm{n}=$ 95, $\mathrm{p}=0.004$; Series 3: $\mathrm{r}=0.52, \mathrm{n}=95, \mathrm{p}<0.001$; Series 5: $\mathrm{r}=0.32, \mathrm{n}=95, \mathrm{p}=0.002)$ and when all data were combined ( $\mathrm{r}=0.21, \mathrm{n}=475, \mathrm{p}<0.001$, see also Fig. 4). These correlations were not improved substantially by lagging $1 \mathrm{~d}$.

\section{Verification of independence among daily egg cohorts}

Spawning in the PRE started near nautical twilight (NT) on both dates, with the first fertilized eggs appearing at 20:00 and 20:10 h (Fig. 9). Between 94 and $100 \%$ of the eggs were fertilized. No unfertilized eggs were found among the many thousands of late- times identified the mean egg development time as 23 to $24 \mathrm{~h}$. Mean water temperatures were 25.2 and $25.5^{\circ} \mathrm{C}$ on the 2 dates. Both spawning and hatching were slightly protracted, causing temporal overlap between the 2 daily cohorts during the period from NT to NT + $2.5 \mathrm{~h}$. Only 1 cohort was present at all other times, including the time of the 25 surveys in the MRE. Spawning times, spawning durations and egg development times in the Tampa Bay area were very similar to those reported for more northerly locations by Luo \& Musick (1991) and Zastrow et al. (1991), verifying the independence of cohorts collected during the 25 MRE surveys.

\section{DISCUSSION}

Collectively, reports of the relative buoyancy of bay anchovy eggs at various salinities indicate that the eggs are buoyant when salinities are higher than approximately 14 psu (Jones et al. 1978, MacGregor \& Houde 1996, Rilling \& Houde 1999a). At these higher salinities, eggs tend to be much more abundant above 

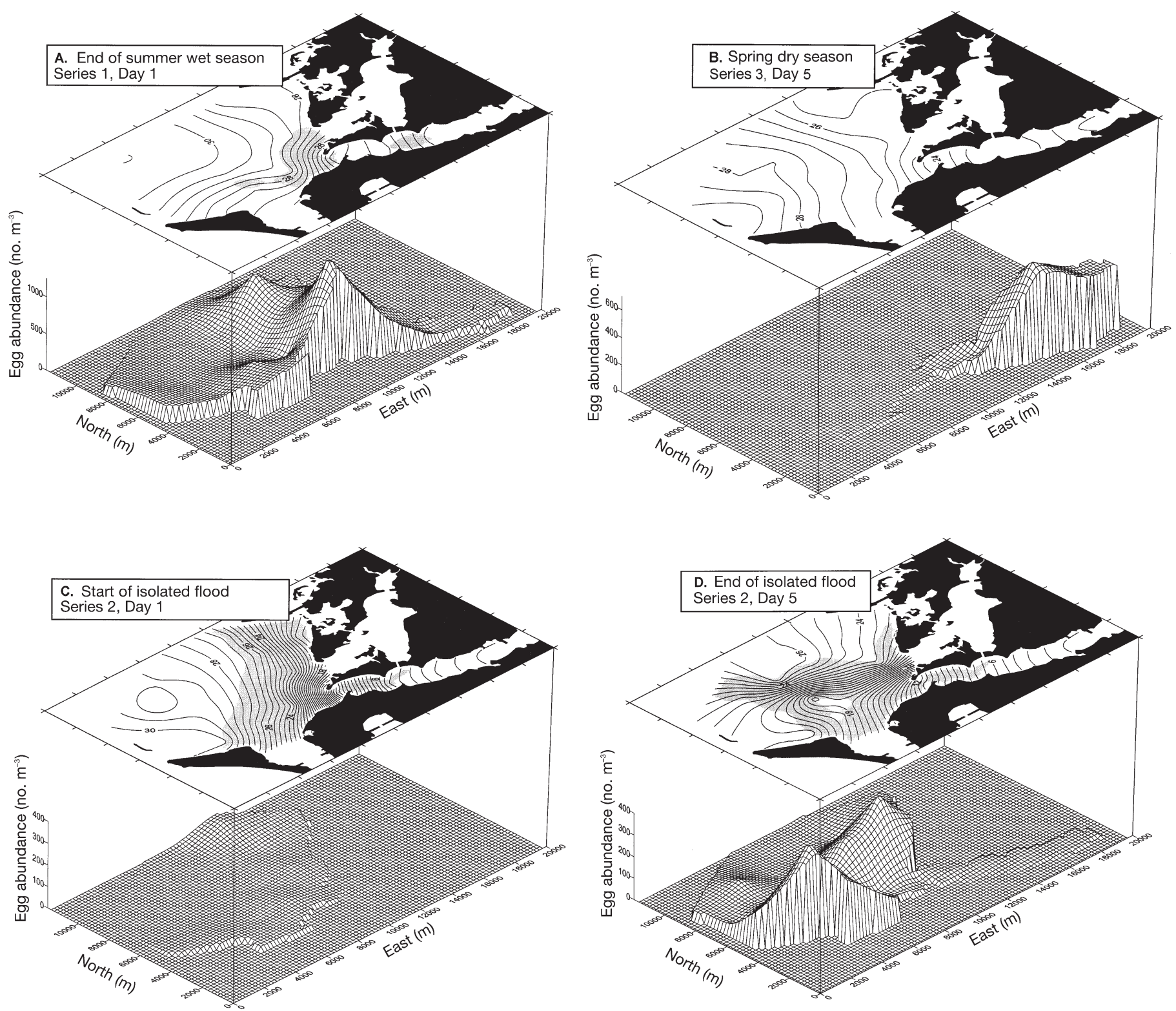

Fig. 5. Relationship between egg abundance and salinity structure during (A) a wet season, (B) a dry season, (C) the onset of a strong flood event, and (D) the end of a strong flood event. Shaded areas have a salinity slope $>1.0 \mathrm{psu} \mathrm{km}^{-1}$. Isohalines are spaced at 0.5 psu intervals

Table 2. Comparison of regressor fit calculated by holding other regressors constant (see text), ranked by partial coefficient of determination. $\mathrm{ns}=$ not significant $(\mathrm{p}>0.05)$

\begin{tabular}{|c|c|c|c|c|c|}
\hline Prey availability regressor & & $r^{2}(\%)$ & Front-related regressor & & $r^{2}(\%)$ \\
\hline Pre-spawn Acartia tonsa aggregation $\left(A A_{\text {pre }}\right)$ & + & 40.9 & Post-spawn salinity mean ( $\left.F M_{\text {post }}\right)$ & + & 20.4 \\
\hline Pre-spawn Acartia tonsa number $\left(A N_{\text {pre }}\right)$ & + & 40.8 & Post-spawn front strength $\left(F S_{\text {post }}\right)$ & - & 17.7 \\
\hline Post-spawn Acartia tonsa number ( $\left.A N_{\text {post }}\right)$ & + & 18.1 & Post-spawn front area $\left(F A_{\text {post }}\right)$ & - & 17.0 \\
\hline \multirow{5}{*}{\multicolumn{2}{|c|}{ Post-spawn Acartia tonsa aggregation $\left(A A_{\text {post }}\right)+$}} & 17.9 & Pre-spawn salinity mean $\left(F M_{\text {pre }}\right)$ & + & 3.9 \\
\hline & & & Pre-spawn salinity SD $\left(F V_{\text {pre }}\right)$ & $\mathrm{ns}$ & 3.1 \\
\hline & & & Post-spawn salinity $\mathrm{SD}\left(F V_{\text {post }}\right)$ & ns & 3.0 \\
\hline & & & Pre-spawn front strength $\left(F S_{\text {pre }}\right)$ & ns & 2.9 \\
\hline & & & Pre-spawn front area $\left(F A_{\text {pre }}\right)$ & ns & 2.6 \\
\hline
\end{tabular}




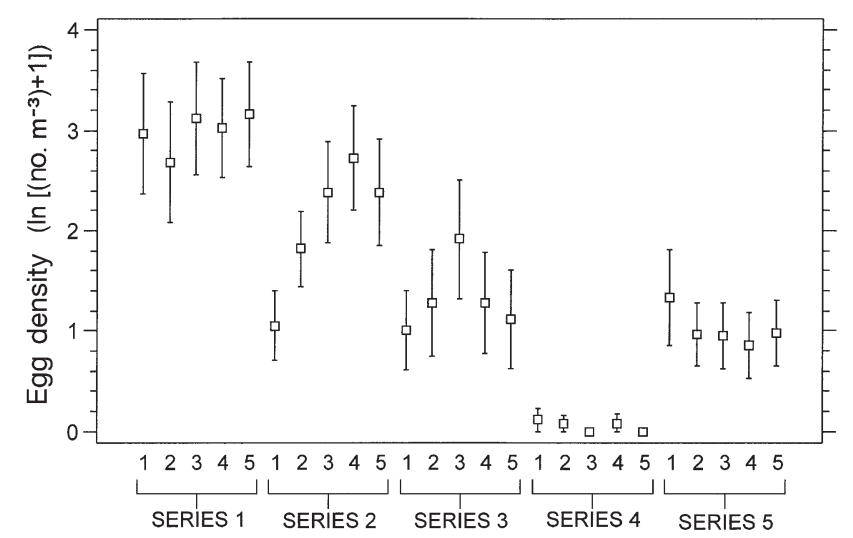

Fig. 6. Variation in instantaneous egg densities among the 25 surveys (mean with $\mathrm{SE}, \mathrm{n}=19$ for each survey)

the pycnocline than below it (MacGregor \& Houde 1996, Rilling \& Houde 1999a). In the MRE, egg densities typically decreased rapidly with distance upstream from the area of peak abundance, as illustrated by Figs. 4 \& 5a,d. One explanation for the rapid upstream decrease would be a reduction in buoyancy at reduced salinities, which would cause a reduction in the num-

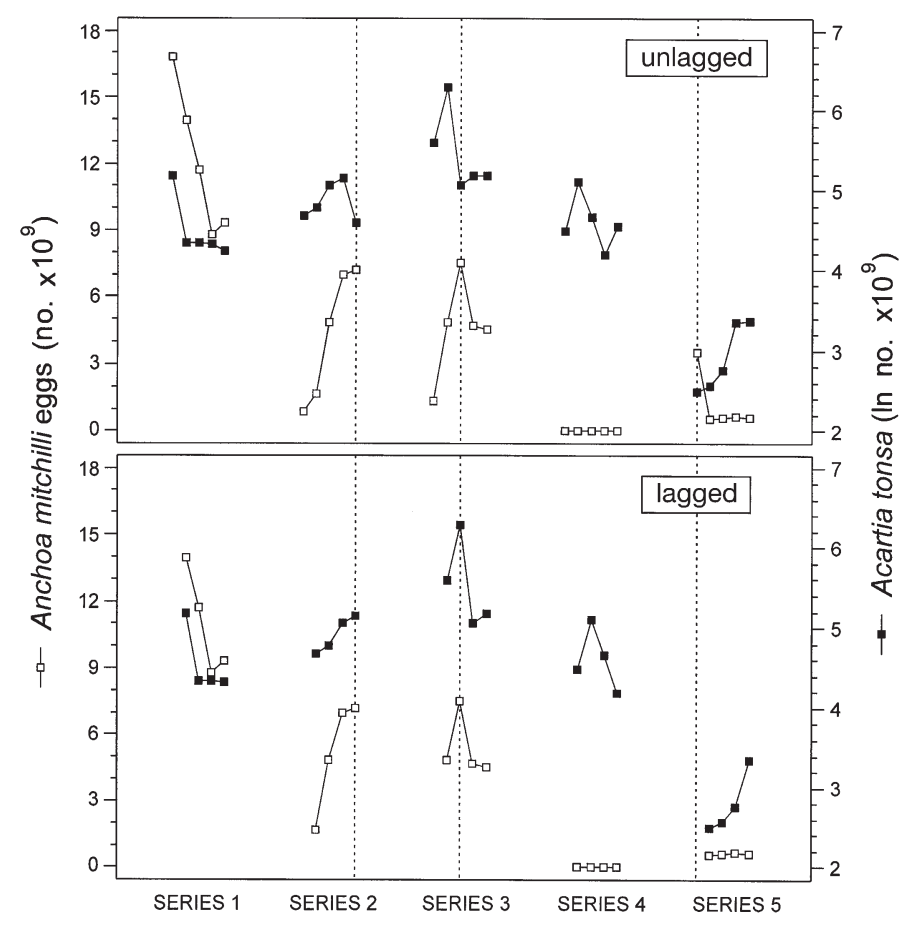

Fig. 8. Comparison of $1 \mathrm{~d}$ lagged (pre-spawning) and unlagged (post-spawning) associations between total egg number and total Acartia tonsa number $(A N)$. Vertical lines identify data pairs that strongly detracted from (unlagged) or aided (lagged) explanation of variation in egg number among surveys

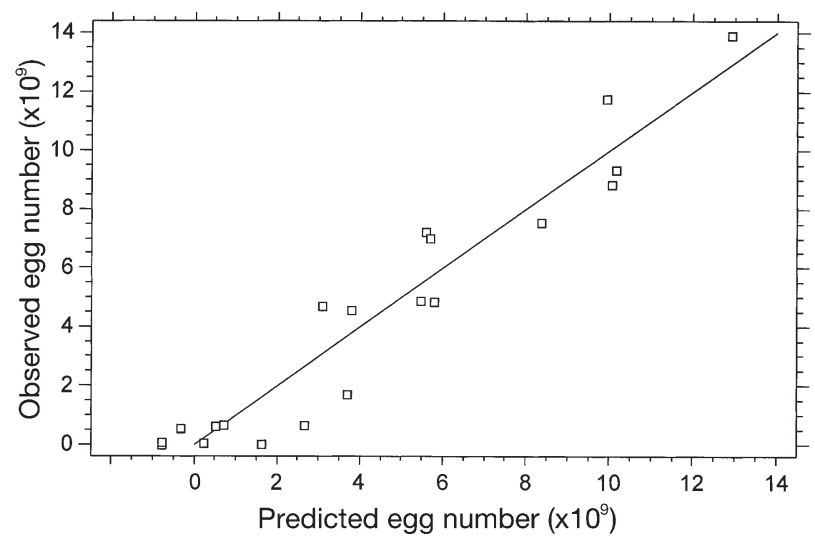

Fig. 7. Performance of the stepwise regression. No. of eggs $\left(\times 10^{6}\right)=-79133+3813 \ln A N_{\text {pre }}+1541 T+420 F M_{\text {post }}+21 P$, where $A N_{\text {pre }}$ is pre-spawn Acartia tonsa number, $T$ is water temperature, $F M_{\text {post }}$ ist post-spawn salinity mean and $P$ is photoperiod $\left(n=20, p<0.0001, r^{2}=0.92\right)$

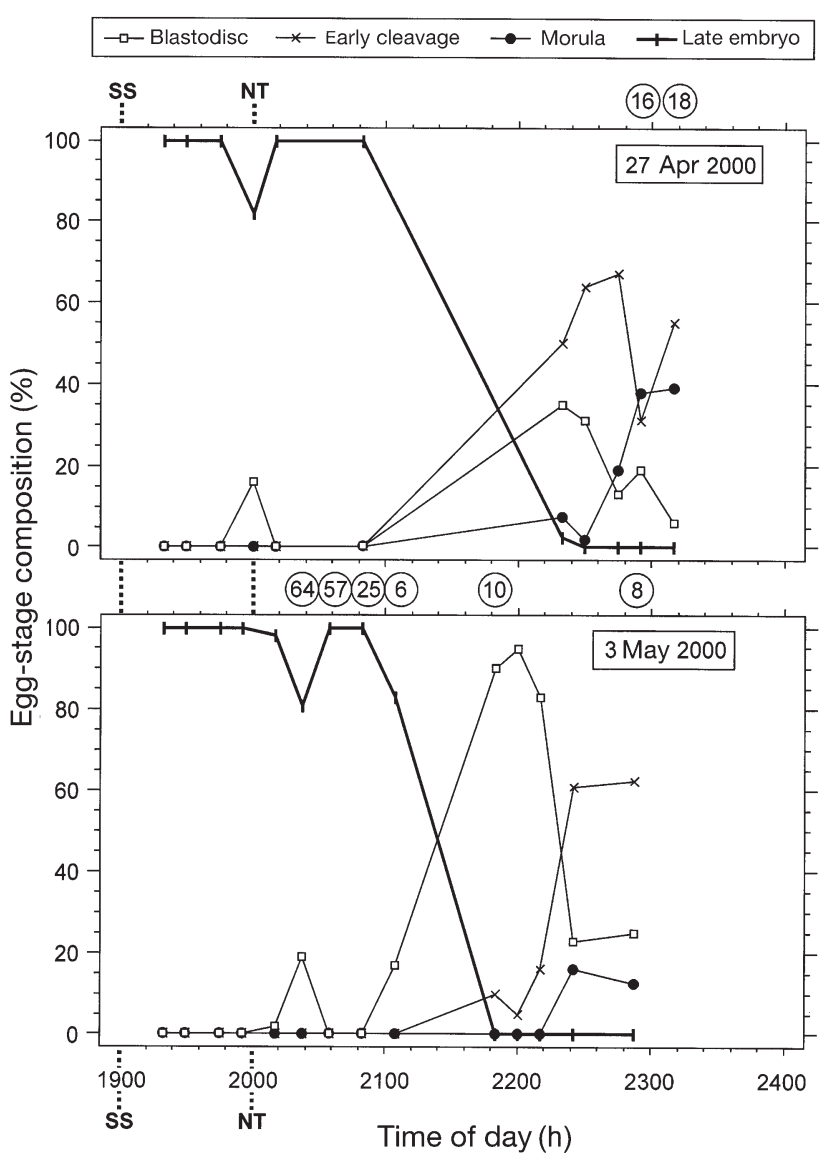

Fig. 9. Time series (Eastern Standard Time) of egg-stage composition in the Palm River estuary survey area. SS: sunset; NT: nautical twilight. Numbers in circles indicate sample sizes $<100$; all other sample sizes are 100 

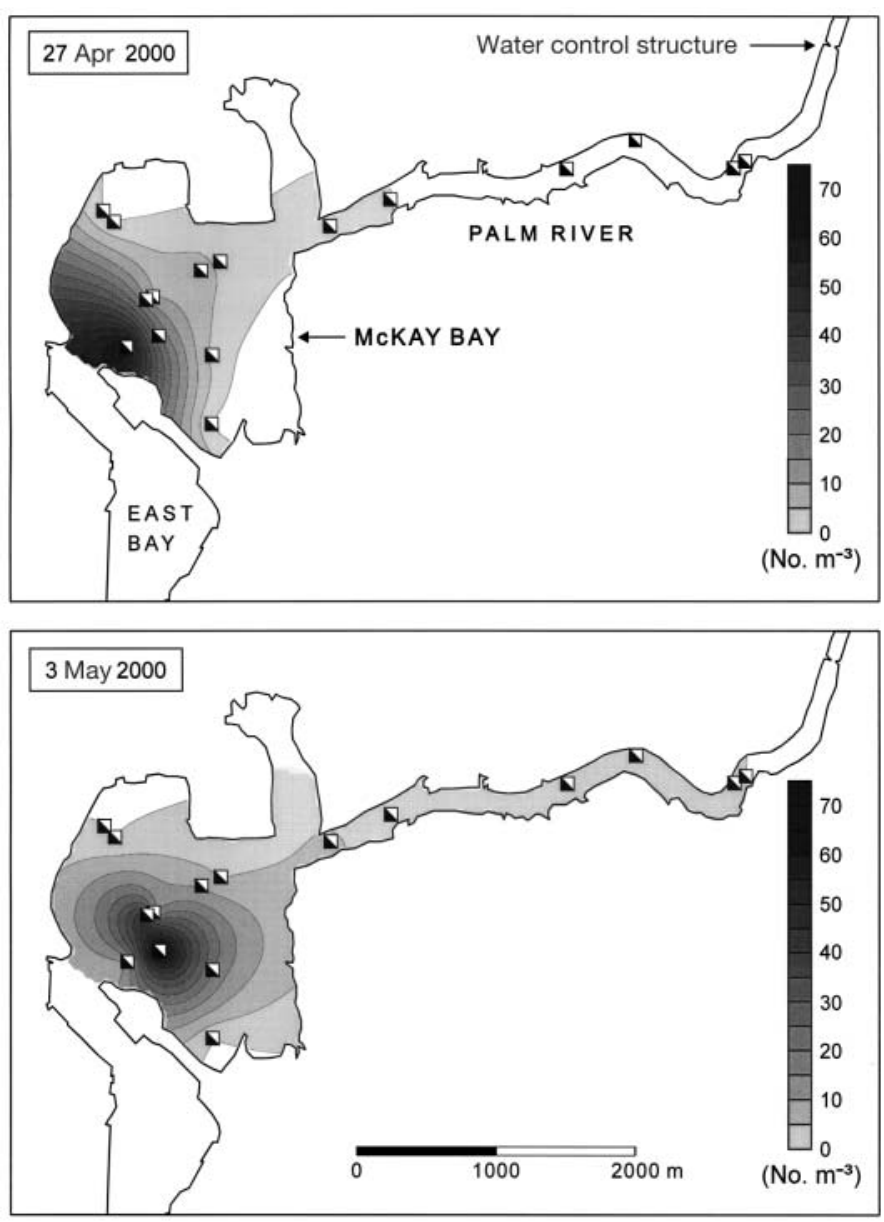

Fig. 10. Egg distribution during construction of the time series in Fig. 9. Symbols identify collection locations

ber collected by surface tows. However, the rapid upstream decrease was also observed in oblique-tow data, and both deployment methods indicated that the upstream zone of decrease was consistently contained within salinities $>14$ psu. Upstream of the $14 \mathrm{psu}$ isohaline, mean densities from oblique tows were $<0.2$ eggs $\mathrm{m}^{-3}$, indicating that the proportion of eggs suspended at depth within the lower salinity reaches of the river could not have been large. Given the relatively high salinities in the MRE spawning area, tows deployed throughout the water column would have arbitrarily reduced apparent egg abundance as a function of station depth. Surface tows were therefore considered to be preferable.

The apparent number of eggs in the MRE changed substantially within a few days. Copepod abundance also exhibited strong daily fluctuations, which can be attributed to estuarine retention variability, mortality and rapid copepodite growth. In high-nutrient environments with warm temperatures, copepodites re- quire $<2 \mathrm{~d}$ to grow from sizes that would pass through large meshes to sizes that would be fully retained (Hopcroft et al. 1998).

Acartia tonsa abundance prior to spawning explained $40.8 \%$ of the variation in egg abundance, whereas abundance after spawning explained only $18.1 \%$ (Table 2 ). The lagged nature of the correlation, which is illustrated without any multivariate context in Fig. 8, suggests that the eggs and copepods are not simple covariates of watermass movement. Instead, these results support the hypothesis that prey availability prior to spawning is a determinant of spawning intensity (Luo \& Musick 1991, Peebles et al. 1996, Hood et al. 1999, Lapolla 2001). Hay \& Brett (1988) and Milton et al. (1994) reported dependence of sizespecific fecundity on prey availability for several species of clupeoid fishes. In these relationships, the process of fat storage intervened between increased adult ration and elevated egg production, and this intervention interfered with instantaneous correlations between prey availability and fecundity. Similarly, Tsuruta \& Hirose (1989) found an 11 to $21 \mathrm{~d}$ lag between elevations in ration (dry food pellets) and egg production in captive Japanese anchovies. In the case of bay anchovy, spawning energy may be derived more from recent (daily) feeding than from fat reserves (Luo \& Musick 1991, Wang \& Houde 1994). As a result, the ration-to-egg lag appears to be largely eliminated. Peebles et al. (1996) discuss the advantages that this reflex would have in the context of estuarine spatiotemporal heterogeneity.

In contrast to the prey regressors, front regressors explained more variation in egg abundance when post-spawning values were used (20.4 vs $3.9 \%$ in the case of mean salinity), which agrees with the timing of a retention-related process. Egg production appears to be initially controlled by prey availability and temperature, after which egg abundance becomes modified by front-related retention processes.

Although vertical motion and turbulence occur at frontal interfaces, fronts exist because of resistance to mixing. Tidal intrusion fronts (cf. O'Donnell 1993) may either facilitate or restrict organism dispersal (Yanagi et al. 1992, Shen et al. 1999), whereas river plume fronts tend to act as barriers to dispersal (Pinckney \& Dustan 1990, Largier 1993). Except under very high inflows, the fronts in the RPFZ were transverse to the channel, forming an effective barrier that differs from the often longitudinal frontal systems that are associated with tidal intrusion. The exception to this trend was the large plume front that evolved at the onset of the isolated flood event (Series 2). Eggs that were previously spawned on the seaward side of this developing plume front would have been pushed seaward and, conversely, eggs that were spawned on the landward side 
of the more stable fronts at the river mouth (e.g. Series 1) would be more likely to be retained within the river. The effect of freshwater inflows on egg abundance in the MRE is nonlinear (Fig. 11). While the relationship in Fig. 11 fits the data, it offers little insight into causes of variation in egg abundance. The multiple regression approach provided more opportunity to investigate causative processes, and produced comparable fit to the data. The principal drawback to the regression approach was its inability to accommodate nonlinear relationships. The regression analysis identified the post-spawning salinity mean as the best representative of front strength because the mean provided the most linear relationship with residual egg abundance. If the model were to be applied to extreme drought conditions, it would tend to overestimate egg abundance due to linear extrapolation of the positive benefits of retention, as represented by mean salinity. The most informative products of the regression-based approach were the temporal comparisons. In the case of the front-related (retention-related) regressors, the better performance of post-spawning values over prespawning values held regardless of the metric used (mean salinity, front strength or front area, Table 2).

At one extreme of the nonlinear relationship, prolonged dry periods reduce egg production by reducing prey availability; the lowest Acartia tonsa numbers were associated with low salinity standard deviations (dry periods). Series 3 data indicate that the river mouth A. tonsa patch persisted and apparently flourished for at least $25 \mathrm{~d}$ after cessation of elevated inflows, although this observation was made during a dry period that followed unusually large nutrient loadings. Primary production is often elevated due to increased

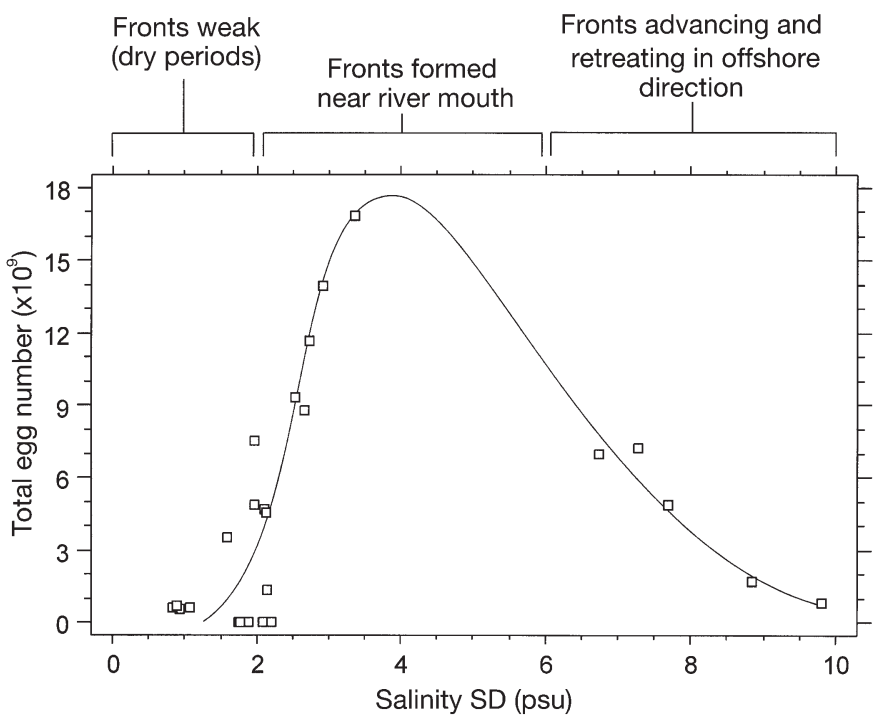

Fig. 11. Egg abundance versus salinity SD, with a curve fitted by eye water clarity and residence time during initial stages of droughts (Livingston 1997, Mallin et al. 1999). Livingston's data indicate that the increased production at the onset of dry periods eventually becomes unsustainable and declines to below-average values unless nutrient loading resumes via renewal of freshwater inflows. Series 5, which was more representative of a typical spring dry season than Series 3, had the lowest $A$. tonsa numbers observed and also had very low egg numbers, in agreement with Livingston's sustainability observations. At the other extreme, the seaward-moving RPFZ at the onset of Series 2 exported eggs or possibly caused a pre-emptive reduction in spawning intensity. At intermediate inflow levels, egg abundance was at a maximum due to the coupling of good retention with good prey availability.

A pattern evident among the egg and copepod spatial distributions was the lack of association between eggs and the Acartia tonsa patches that occurred in deeper water away from the river mouth, which gave the impression that strong tidal currents constrained the area of the spawning ground in a manner similar to that reported by Hay (1990) for Pacific herring. Because the tide-based regressors in the stepwise regression did not explain a significant amount of temporal variation in egg abundance, this potential constraint does not appear to have a strong temporal component. During all but a few surveys, peak egg abundance occurred within the river or in nearby waters that have $30 \mathrm{~d}$ average surface velocities $<0.1 \mathrm{~m} \mathrm{~s}^{-1}$ (Burwell et al. 1999). Farther offshore in the tidal intrusion frontal zone (TIFZ), surface velocities average nearly $0.2 \mathrm{~m} \mathrm{~s}^{-1}$ and regularly exceed $0.8 \mathrm{~m} \mathrm{~s}^{-1}$. As would be expected, Lagrangian retention times are sharply reduced in the TIFZ (Burwell et al. 1999). The eggs collected during the surveys had been subject to dispersal for $<18 \mathrm{~h}$, whereas the adult $A$. tonsa would have been a minimum of 7 to $9 \mathrm{~d}$ old (Heinle 1966, Ogle 1979), subjecting them to much greater dispersal.

Development of offshore Acartia tonsa patches was strongest during rainy periods, following the same pattern observed in upper Tampa Bay by Peebles et al. (1996). The offshore patches varied in size and location compared with the more predictable patch that was nearly always present at the river mouth. The presence of A. tonsa patches away from the river mouth interfered with positive correlations between the instantaneous densities of $A$. tonsa and bay anchovy eggs. In general, detection of spatial associations between bay anchovy eggs and zooplankton has been inconsistent (Rilling \& Houde 1999a), in part because detection is sensitive to the spatial scale of the sampling design (Rose \& Leggett 1990). Nevertheless, the 2 organisms were correlated during dry periods and when all data were considered together (Fig. 4). 
From the standpoint of recruitment of larvae, juveniles or adults, it cannot be assumed that the supply of eggs is constant for any length of time. The present work indicates that spatio-temporal spawning modulation is likely to eliminate catastrophic (starvationinducing) mismatches between bay anchovy larvae and their prey, and so will periodically limit the supply of eggs. When eggs are in short supply, the resulting recruitment will certainly be low. Lapolla (2001) attributed the end of the bay anchovy spawning season in Narragansett Bay to decreased zooplankton abundance and found the best juvenile recruitment to be associated with known zooplankton-rich periods.

Spawning modulation requires high iteroparity and a fast response time in order to match the scale of the variability in the estuarine larval habitat. The mechanism is clearly not refined to the extent that it prevents spatio-temporal variation in larval growth rate (Rilling \& Houde 1999b, Jordan et al. 2000, Fulling 2001). Variation in growth rate, in turn, is likely to translate into variation in mortality rate (e.g. Ware 1975). Spawning modulation of the type observed here would nearly eliminate starvation-inducing mismatch without necessarily eliminating ration-related variation in larval mortality rate. Even when initial egg supplies are high, recruitment is still likely to be variable due to variation in losses during the egg, larval and juvenile stages (Stephens et al. 1986, Peterman et al. 1988). Iteroparity in the bay anchovy, therefore, can be viewed as a means of adjusting reproductive effort to factors that will affect initial larval survival.

Acknowledgements. I am indebted to Ralph Kitzmiller (USF), who enumerated the eggs and copepods. The challenging field efforts also could not have been completed without his efforts, as well as those of Erik Nelson and Pat Cannizzaro (USF). Dr. Ed Matheson (Florida Marine Research Institute) reviewed the first draft of this manuscript. Funding for this investigation was provided by the Southwest Florida Water Management District, with Michael Flannery serving as project manager.

\section{LITERATURE CITED}

Bagenal TB (1973) Fish fecundity and its relation with stock and recruitment. Rapp P-V Reun Cons Int Explor Mer 164: 186-198

Burwell D, Vincent M, Luther M, Galperin B (1999) Modeling residence times: Eulerian vs Lagrangian. In: Spaulding ML, Butler HL (eds) Proceedings of the 6th International Conference on Estuarine and Coastal Modeling. American Society of Civil Engineers, New Orleans, p 995-1009

Castro LR, Cowen RK (1991) Environmental factors affecting the early life history of the bay anchovy Anchoa mitchilli in Great South Bay, New York. Mar Ecol Prog Ser 76: 235-247

Cowan JH Jr, Houde ED (1990) Growth and survival of bay anchovy Anchoa mitchilli larvae in mesocosm enclosures. Mar Ecol Prog Ser 68:47-57
Cowan JH Jr, Houde ED (1993) Relative predation potentials of scyphomedusae, ctenophores and planktivorous fish on ichthyoplankton in Chesapeake Bay. Mar Ecol Prog Ser 95:55-65

Cushing DH (1990) Plankton production and year-class strength in fish populations: an update of the match/mismatch hypothesis. Adv Mar Biol 26:249-293

Dagg MJ, Whitledge TE (1991) Concentrations of copepod nauplii associated with the nutrient-rich plume of the Mississippi River. Cont Shelf Res 11:1409-1423

Darnell RM (1961) Trophic spectrum of an estuarine community, based on studies of Lake Pontchartrain, Louisiana. Ecology 42:553-568

David FN, Moore PG (1954) Notes on contagious distributions in plant populations. Ann Bot 18:47-53

Dorsey SE, Houde ED, Gamble JC (1996) Cohort abundances and daily variability in mortality of eggs and yolk-sac larvae of bay anchovy, Anchoa mitchilli, in Chesapeake Bay. Fish Bull 94:257-267

Draper NR, Smith H (1998) Applied regression analysis. John Wiley \& Sons, New York

Fulling GL (2001) Plankton patchiness and the associated distribution and growth of larval anchovies: an estuarine landscape perspective. $\mathrm{PhD}$ thesis, University of Southern Mississippi, Hattiesburg

Govoni JJ, Hoss DE, Colby DR (1989) The spatial distribution of larval fishes about the Mississippi River plume. Limnol Oceanogr 34:178-187

Hay DE (1990) Tidal influence on spawning time of Pacific herring (Clupea harengus pallasi). Can J Fish Aquat Sci 47:2390-2401

Hay DE, Brett JR (1988) Maturation and fecundity of Pacific herring (Clupea harengus pallasi): an experimental study with comparisons to natural populations. Can J Fish Aquat Sci 45:399-406

Heinle DR (1966) Production of a calanoid copepod, Acartia tonsa, in the Patuxent River estuary. Chesapeake Sci 7 : $59-74$

Holt GJ, Holt SA, Arnold CR (1985) Diel periodicity of spawning in sciaenids. Mar Ecol Prog Ser 27:1-7

Hood RR, Wang HV, Purcell JE, Houde ED, Harding LW Jr (1999) Modeling particles and pelagic organisms in Chesapeake Bay: convergent features control plankton distributions. J Geophys Res 104:1223-1243

Hopcroft RR, Roff JC, Weber MK, Witt JDS (1998) Zooplankton growth rates: the influence of size and resources in tropical marine copepodites. Mar Biol 132:67-77

Hopkins TL (1977) Zooplankton distribution in surface waters of Tampa Bay, Florida. Bull Mar Sci 27:467-478

Houde ED, Lovdal JA (1984) Seasonality of occurrence, foods and food preferences of ichthyoplankton in Biscayne Bay, Florida. Estuar Coast Shelf Sci 18:403-419

Iseki K, Kiyomoto Y (1997) Distribution and settling of Japanese anchovy (Engraulis japonicus) eggs at the spawning ground off Changjiang River in the East China Sea. Fish Oceanogr 6:205-210

Johnson WS, Allen DM, Ogburn MV, Stancyk SE (1990) Short-term predation responses of adult bay anchovies Anchoa mitchilli to estuarine zooplankton availability. Mar Ecol Prog Ser 64:55-68

Jones PW, Martin FD, Hardy JD Jr (1978) Development of fishes of the mid-Atlantic Bight: an atlas of egg, larval, and juvenile stages. Vol I: Acipenseridae through Ictaluridae. U.S. Fish and Wildlife Service, Office of Biological Programs. FSW/OBS-78/12. Ft. Collins, CO

Jordan RC, Gospodarek AM, Schultz ET, Cowen RK, Lwiza K (2000) Spatial and temporal growth rate variation of bay 
anchovy (Anchoa mitchilli) larvae in the mid Hudson River Estuary. Estuaries 23:683-689

Lapolla AE (2001) Bay anchovy Anchoa mitchilli in Naragansett Bay, Rhode Island. II. Spawning season, hatchdate distribution and young-of-the-year growth. Mar Ecol Prog Ser 217:103-109

Largier JL (1993) Estuarine fronts: how important are they? Estuaries 16:1-11

Livingston RJ (1997) Trophic response of estuarine fishes to long-term changes of river runoff. Bull Mar Sci 60: 984-1004

Lohrenz SE, Dagg MJ, Whitledge TE (1990) Enhanced primary production at the plume/oceanic interface of the Mississippi River. Cont Shelf Res 10:639-664

Luo J, Musick JA (1991) Reproductive biology of the bay anchovy in Chesapeake Bay. Trans Am Fish Soc 120: 701-710

MacGregor JM, Houde ED (1996) Onshore-offshore pattern and variability in distribution and abundance of bay anchovy Anchoa mitchilli eggs and larvae in Chesapeake Bay. Mar Ecol Prog Ser 138:15-25

Mallin MA, Cahoon LB, McIver MR, Parsons DC, Shank GC (1999) Alternation of factors limiting phytoplankton production in the Cape Fear River Estuary. Estuaries 22: 825-836

Milton DA, Blaber SJ, Rawlinson NJF (1994) Reproductive biology and egg production of three species of Clupeidae from Kiribati, tropical central Pacific. Fish Bull US 92: 102-121

Monteleone DM, Duguay LE (1988) Laboratory studies of predation by the ctenophore Mnemiopsis leidyi on the early stages in the life history of the bay anchovy, Anchoa mitchilli. J Plankton Res 10:359-372

O'Donnell J (1993) Surface fronts in estuaries: a review. Estuaries 16:12-39

Ogle J (1979) Adaptation of a brown water culture technique to the mass culture of the copepod Acartia tonsa. Gulf Res Rep 6:291-292

Peebles EB, Hall JR, Tolley SG (1996) Egg production by the bay anchovy Anchoa mitchilli in relation to adult and larval prey fields. Mar Ecol Prog Ser 131:61-73

Peterman RM, Bradford MJ, Lo NCH, Methot RD (1988) Contribution of early life stages to interannual variability in recruitment of northern anchovy (Engraulis mordax). Can J Fish Aquat Sci 45:8-16

Pinckney J, Dustan P (1990) Ebb-tidal fronts in Charleston Harbor, South Carolina: physical and biological characteristics. Estuaries 13:1-7

Plagányi EE, Hutchings L, Field JG (2000) Anchovy foraging:

Editorial responsibility: Ronald Kneib (Contributing Editor), Sapelo Island, Georgia, USA simulating spatial and temporal match/mismatches with zooplankton. Can J Fish Aquat Sci 57:2044-2053

Purcell JE, Nemazie DA, Dorsey SE, Houde ED, Gamble JC (1994) Predation mortality of bay anchovy Anchoa mitchilli eggs and larvae due to scyphomedusae and ctenophores in Chesapeake Bay. Mar Ecol Prog Ser 114:47-58

Rilling GC, Houde ED (1999a) Regional and temporal variability in distribution and abundance of bay anchovy (Anchoa mitchilli) eggs, larvae, and adult biomass in the Chesapeake Bay. Estuaries 22:1096-1109

Rilling GC, Houde ED (1999b) Regional and temporal variability in growth and mortality of bay anchovy (Anchoa mitchilli) larvae in the Chesapeake Bay. Fish Bull US 97: 555-569

Rose GA, Leggett WC (1990) The importance of scale to predator-prey spatial correlations: an example of Atlantic fishes. Ecology 71:33-43

Ryan TP (1997) Modern regression methods. John Wiley \& Sons, New York

Shen J, Boon JD, Kuo AY (1999) A modeling study of a tidal intrusion front and its impact on larval dispersion in the James River estuary, Virginia. Estuaries 22:681-692

Sheridan PF (1978) Food habits of the bay anchovy, Anchoa mitchilli, in Apalachicola Bay, Florida. Northeast Gulf Sci $2: 126-132$

Stephens JS Jr, Jordan GA, Morris PA, Singer MM, McGowen GE (1986) Can we relate larval fish abundance to recruitment or population stability? A preliminary analysis of recruitment to a temperate rocky reef. CalCOFI Rep. 27: $65-83$

Tsuruta Y, Hirose K (1989) Internal regulation of reproduction in the Japanese anchovy (Engraulis japonica) as related to population fluctuation. Can Spec Publ Fish Aquat Sci 108: 111-119

Yanagi T, Matsuda O, Tanabe S, Uye S (1992) Interdisciplinary study on the tidal front in the Bungo Channel, Japan. In: Prandle D (ed) Dynamics and exchanges in estuaries and the coastal zone. American Geophysical Union, Washington, DC, p 617-630

Wang SB, Houde ED (1994) Energy storage and dynamics in bay anchovy Anchoa mitchilli. Mar Biol 121:219-227

Ware DM (1975) Growth, metabolism, and optimal swimming speed of a pelagic fish. J Fish Res Board Can 32:33-41

Ware DM (1980) Bioenergetics of stock and recruitment. Can J Fish Aquat Sci 37:1012-1024

Zastrow CE, Houde ED, Morin LG (1991) Spawning, fecundity, hatch-date frequency and young-of-the-year growth of bay anchovy Anchoa mitchilli in mid-Chesapeake Bay. Mar Ecol Prog Ser 73:161-171

Submitted: September 20, 2001; Accepted: January 26, 2002 Proofs received from author(s): July 3, 2002 